DOI $10.14746 / \mathrm{ssp} .2014 .1 .11$

Małgorzata ADAMIK-SZYSIAK

Uniwersytet Marii Curie-Skłodowskiej w Lublinie

\title{
Kampanie profrekwencyjne a postawy Polaków w kontekście wyborów do Parlamentu Europejskiego
}

\section{Uwagi wstępne}

Wykorzystywanie narzędzi marketingowych w celu osiagnięcia wyznaczonych celów jest w dzisiejszym świecie niemal standardem. Do reguł marketingu ekonomicznego odwołują się nie tylko podmioty polityczne, ale także coraz częściej organizacje społeczne.

Wyłoniony z marketingu politycznego marketing społeczny definiowany jest jako ,zespół technik informacyjnych i perswazyjnych, stosowanych w przedsięwzięciach lub inicjatywach podejmowanych przez instytucje publiczne i obywateli, dotyczących ważnych problemów społecznych. Celem tych działań jest wyłonienie określonych skutków w postaci zachowań i postaw zgodnych z interesem ogółu społeczeństwa" (Dobek-Ostrowska, 2004, s. 233-234).

Zasadniczą cechą odróżniającą marketing społeczny od marketingu politycznego i wyborczego jest orientacja na obywatela, jako konsumenta usług publicznych (nie wyborcę), w założeniu zatem marketing społeczny ma służyć celom ogólnoludzkim, zaspokajać wyższe potrzeby niematerialne (społeczne, intelektualne, emocjonalne), promować preferowane postawy i zachowania społeczne, dobra o uniwersalnym znaczeniu. Marketing społeczny służy zatem demokracji i budowie społeczeństwa obywatelskiego (Dobek-Ostrowska, 2004, s. 234). W przeciwieństwie do marketingu politycznego i wyborczego efekty zastosowania technik marketingu społecznego uwidaczniają się dopiero w dłuższej perspektywie oddziaływania. Jednak w przypadku kampanii profrekwencyjnych, prowadzonych zwykle w związku ze zbliżającymi się wyborami, ich skuteczność zazwyczaj mierzona jest krótko po elekcji, miernikiem natomiast staje się frekwencja wyborcza.

Główne refleksje badawcze w artykule koncentrują się przyczynach absencji wyborczej, a także na zastosowanych narzędziach marketingo- 
wych mających w zamierzeniu nakłonić obywateli do czynnego udziału w wyborach do Parlamentu Europejskiego. Szczególną uwagę zwrócono na intensywność i różnorodność (w tym zawartość) głównych przekazów rozpowszechnianych $\mathrm{w}$ ramach kampanii profrekwencyjnych prowadzonych na poziomie ogólnopolskim. Okresem badania empirycznego objęto zatem dwie dotychczasowe polskie kampanie poprzedzające wybory do Parlamentu Europejskiego w 2004 i w 2009 roku.

Interesujące w kontekście tematu rozważań jest wykorzystanie przez podmioty konstruujące kampanie profrekwencyjne wyników badań rynku wyborczego, w tym preferowanych przez odbiorców kanałów komunikowania. Uwagę zwrócono również na rolę przypisywaną mediom w kształtowaniu świadomości społecznej (media effect) w odniesieniu do znaczenia eurowyborów. Celem podjętej analizy zawartości jest weryfikacja hipotezy dotyczącej istotnej roli przekazów audiowizualnych i interaktywnych w strategiach komunikacyjnych w polskich kampaniach profrekwencyjnych, co jest konsekwencją kierowania komunikatów głównie do młodego pokolenia wyborców.

Teoretyczną podstawą badań jest szeroko pojmowana koncepcja framingu (uramowienia), której rozumienie przyjęto za Robertem Entmanem, wedle którego „tworzyć ramy to znaczy wybierać niektóre aspekty postrzeganej rzeczywistości i nadawać im większe znaczenie w przekazie komunikacyjnym w taki sposób, aby rozpowszechniać określone spojrzenie na problem, interpretację przyczynową, ocenę moralną oraz/lub zalecenie postępowania wobec opisywanego przedmiotu tych działań" (Entman, 1993, s. 52; McCombs, 2008, s. 101), posiłkowana teorią racjonalnego wyboru, zgodnie z którą wyborca ,podejmując decyzję dokonuje kalkulacji z punktu widzenia swoich korzyści i kosztów” (Raciborski, 1997, s. 20-21).

\section{Frekwencja wyborcza - decyzje wyborcze}

Wybory do Parlamentu Europejskiego ${ }^{1}$ nie cieszą się zbyt dużym zainteresowaniem społeczeństwa polskiego (tab. 1), postrzegane sąjako mniej znaczące, niemające zauważalnego wpływu na życie obywateli, niż wybory samorządowe, prezydenckie i parlamentarne ${ }^{2}$ (zob. Roguska, 2009b,

1 Dalej: PE.

2 Taka kolejność - od najistotniejszych wyborów - została wskazana przez respondentów w badaniu CBOS przeprowadzonym początkiem lipca 2009 r. 
s. 1-2). Niewielkie zainteresowanie kampanią wyborczą, aktem głosowania przekłada się również na niskie zaangażowanie uwagi społeczeństwa wynikami tejże elekcji - w 2009 r. 49\% wszystkich badanych zadeklarowało, że nie interesują ich rezultaty wyborów, aż $70 \%$ ankietowanych nie wiedziało, jakie osoby uzyskały mandat europosła w ich okręgu wyborczym, co dowodzi niemal marginalizacji eurowyborów (zob. Roguska, 2009b, s. 1, 9-10) $)^{3}$.

Tabela 1

Zainteresowanie wyborami do PE w Polsce [\%]

\begin{tabular}{||c|c|c|c|c||}
\hline \multirow{2}{*}{ Odpowiedź } & \multicolumn{2}{|c|}{2004} & \multicolumn{2}{c||}{2009} \\
\cline { 2 - 5 } & marzec & maj & marzec & maj \\
\hline Tak & 40 & 41 & 33 & 38 \\
\hline Nie & 57 & 57 & 63 & 59 \\
\hline Trudno powiedzieć & 3 & 2 & 4 & 3 \\
\hline
\end{tabular}

Źródło: Opracowanie własne na podstawie danych CBOS (Cybulska, 2004b, s. 1-2; Cybulska, 2009, s. 1).

Zainteresowanie wyborami do PE (kampanią oraz wynikami) zarówno w badaniach w 2004, jak również w 2009 roku podkreślały głównie osoby śledzące bieżące wydarzenia w polityce oraz przekonane o zależnościach wizerunku Polski na arenie międzynarodowej i właściwej reprezentacji polskich interesów w Unii Europejskiej ${ }^{4}$ od osób piastujących funkcje europarlamentarzystów. Warto zauważyć, że aktywny udział w wyborach jest ściśle związany z wyższym poziomem wykształcenia oraz sprecyzowanymi poglądami politycznymi.

W 2009 roku wybory do PE w nieco większym stopniu niż w 2004 roku zaistniały w świadomości społecznej (tab. 2). Poziom poinformowania o wyborach nie przełożył się jednak na aktywny udział w głosowaniu. Więcej osób zamierzało uczestniczyć w wyborach niż się nimi interesowało, co oznaczać może, że de facto jedynie chęć wypełnienia obywatelskiego obowiązku. Deklaracje uczestnictwa w wyborach składały w zdecydowanej większości osoby, które aktywnie uczestniczyły również

3 Proporcje te wyglądaja zgoła inaczej wśród głosujących - nazwiska deputowanych $\mathrm{z}$ ich okręgu wyborczego zna $65 \%$ ankietowanych.

4 Dalej: UE. 
we wcześniejszych elekcjach (Cybulska, 2004b, s. 2; Roguska, 2009b, s. $9-10)^{5}$.

Tabela 2

Deklaracja uczestnictwa w wyborach do PE a rzeczywista frekwencja [\%]

\begin{tabular}{||r|c|c|c|c||}
\hline \multirow{2}{*}{ Odpres badania } & \multicolumn{2}{|c|}{2004} & \multicolumn{2}{c|}{2009} \\
\cline { 2 - 5 } & marzec & maj & marzec & maj \\
\hline Tak & 41 & 45 & 39 & 36 \\
\hline Nie & 32 & 32 & 32 & 31 \\
\hline Trudno powiedzieć & 26 & 23 & 29 & 33 \\
\hline Rzeczywista frekwencja & \multicolumn{2}{|c|}{20,87} & \multicolumn{2}{c|}{24,53} \\
\hline
\end{tabular}

Źródło: Opracowanie własne na podstawie danych CBOS oraz PKW (zob. Roguska, 2009b, s. 4-6; PKW 2004; PKW 2009).

Badania przeprowadzone przez CBOS wskazują, że w odniesieniu do wyborów parlamentarnych i prezydenckich decyzje o tym na kogo głosować zapadają znacznie wcześniej, niż w przypadku eurowyborów (zob. Cybulska 2004a, s. 5). Pytani wyborcy wskazywali, że dopiero w dniu wyborów swe preferencje precyzowało odpowiednio w 2004 r. - 27\%, natomiast w 2009 r. $-21 \%$ obywateli, w ostatnim tygodniu kampanii wyborczej w 2004 r. - 18\%, z kolei w 2009 r. - 12\%, wcześniej niż na dwa tygodnie przed wyborami swej decyzji pewnych było w 2004 r. jedynie $41 \%$ wyborców, zaś w 2009 r. - 50\% (tab. 3).

Tabela 3

Sposób podejmowania decyzji wyborczych [\%]

\begin{tabular}{||l|c|c||}
\hline \multicolumn{1}{|c|}{ Okres badania/ Odpowiedź } & $\mathbf{2 0 0 4}$ & $\mathbf{2 0 0 9}$ \\
\hline W dniu wyborów & 27 & 21 \\
\hline W przeddzień wyborów & 5 & 5 \\
\hline W ostatnim tygodniu przed wyborami & 18 & 12 \\
\hline 2 tyg. przed wyborami & 8 & 50 \\
\hline Jeszcze wcześniej & 41 & 2 \\
\hline Trudno powiedzieć & 1 & 11 \\
\hline
\end{tabular}

Źródło: Opracowanie własne na podstawie danych CBOS (Cybulska, 2004a, s. 4-5; Roguska, 2009b, s. 7).

5 Warto zwrócić uwagę, że zarówno w wyborach krajowych, jak i europejskich, średnio 10\% więcej osób deklaruje udział w wyborach, niż rzeczywiście głosuje. 
Badania wykazuja, na stopniowy wzrost personalizacji wyborów nie tylko w rywalizacji wyborczej do Parlamentu RP (Adamik-Szysiak, 2012, s. 211), ale również w kampanii do PE. Na konkretnego kandydata, a nie na ugrupowanie polityczne, które reprezentował, głosowało w 2004 roku $50 \%$ ankietowanych (Cybulska, 2004a, s. 6-7) ${ }^{6}$, z kolei w $2009-54 \%$ (Roguska, 2009b, s. 8).

\section{Przyczyny absencji wyborczej}

Najczęstszymi powodami absencji wyborczej wskazywanymi przez ankietowanych w odniesieniu do obu elekcji, były zniechęcenie sytuacją polityczną w Polsce, a więc odmowa legitymizacji dla aktualnego kształtu sceny politycznej i polityki, brak zainteresowania polityką oraz przekonanie, że wybory sąjedynie pretekstem dla polityków do zdobycia dobrze płatnych posad (rys. 1).

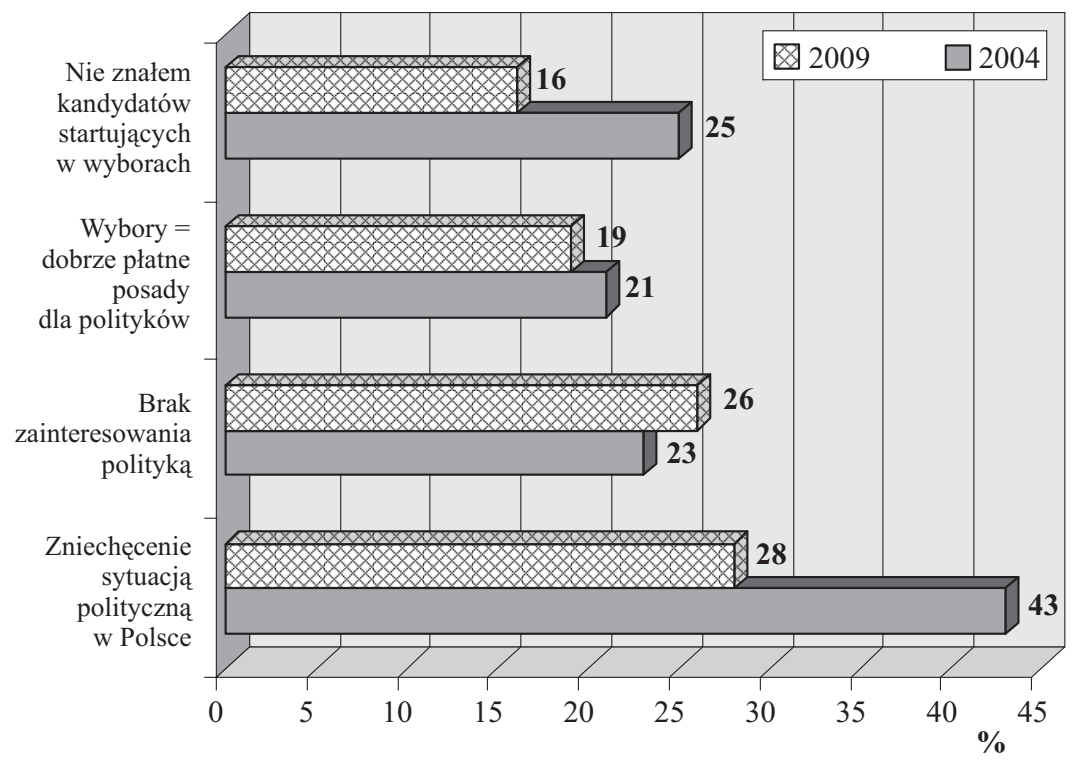

Rys. 1. Najczęściej wskazywane przyczyny absencji wyborczej w 2004 i w 2009 roku Respondenci mogli wskazać 3 powody absencji wyborczej.

Źródlo: Opracowanie własne na podstawie badań CBOS (Cybulska, 2004a, s. 8-9; Roguska, 2009b, s. 8).

${ }^{6} 45 \%$ ankietowanych w swej decyzji kierowało się nazwą komitetu wyborczego, $5 \%$ - nie miało zdania. 
Porównując powody bierności wyborczej w 2004 i w 2009 roku, zauważalna jest dominacja dwóch argumentów: brak zainteresowania polityką oraz zniechęcenie sytuacją polityczną w Polsce, które wyraźnie zdystansowało wszelkie inne powody absencji w pierwszych w Polsce eurowyborach. Uzasadnienia takiej sytuacji można doszukiwać się w okolicznościach poprzedzających elekcję w 2004 roku - wydarzeniach na scenie politycznej, których konsekwencją było ujawnienie kolejnych afer korupcyjnych i politycznych ${ }^{7}$. Deprymacja sytuacją polityczną w 2009 roku mogła być efektem prowadzonej od 2005 roku permanentnej (i od 2006 roku negatywnej $^{8}$ ) kampanii, w której prym wiodły zwalczające się największe ugrupowania Prawo i Sprawiedliwość oraz Platforma Obywatelska.

O rzetelniejszej i w większym stopniu rozpowszechnionej informacji w kampanii wyborczej w 2009 roku może świadczyć spadek w stosunku do 2004 roku liczby osób, które jako przyczynę nieuczestnictwa w wyborach wskazywały brak odpowiednich kandydatów oraz nieznajomość oferty programowej podmiotów (rys. 2).

Niepokojący wydaje się chroniczny deficyt wiedzy obywateli na temat działania instytucji unijnych. Mimo upływu pięciu lat od akcesji Polski do UE część społeczeństwa nadal nie posiada nawet ogólnego zasobu informacji w tym zakresie. Do argumentu wyjaśniającego absencję wyborczą brakiem wiedzy o kompetencjach i funkcjonowaniu Parlamentu Europejskiego odwołała się w 2004 oraz w 2009 roku podobna liczba ankietowanych - odpowiednio: 14\% i 15\% (Cybulska, 2004a, s. 8-9; Roguska, 2009b, s. 8). Inne badania CBOS wskazują nawet, że odsetek społeczeństwa deklarującego wiedzę na temat Parlamentu Europejskiego spada z 25\% w 2005 r. do 14\% w 2009 r. (Roguska, 2009a, s. 4). Co ciekawe, problematyczna jest już sama odpowiedź na pytanie w jaki sposób wybierani są europarlamentarzyści. Z badań przeprowadzonych przez TNS OBOP (na dwa miesiące przed wyborami w 2009 r.) wynika, że takiej wiedzy nie ma niemal połowa Polaków: 29\% badanych było błędnie przeko-

7 Rok 2004 to okres schyłku rządów SLD, w wyniku obnażenia sekwencji afer, w tym tzw. ,afery Rywina” czy ,afery starachowickiej”, sprawujący od 2001 r. funkcję premiera Leszek Miller, zaraz po akcesji Polski do Unii Europejskiej, zrezygnował ze stanowiska, jego miejsce zajął Marek Belka.

8 Przejawy przewagi negatywnej kampanii zauważalne były już w wyborach samorządowych prowadzonych przez partie na poziomie ogólnopolskim, kulminacją tych działań był rok 2007 - kampania parlamentarna. 


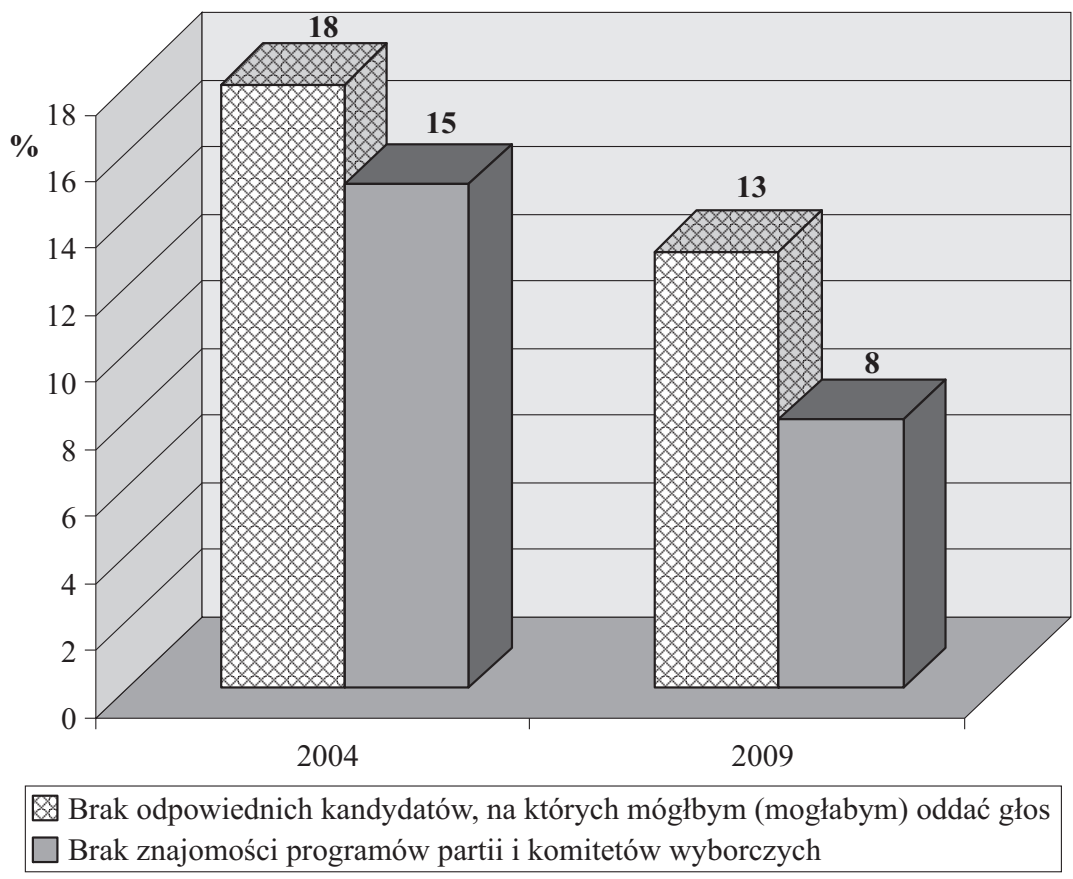

Rys. 2. Brak optymalnych kandydatów oraz nieznajomość oferty programowej, jako powody absencji wyborczej w 2004 i w 2009 roku

Źródło: Opracowanie własne na podstawie badań CBOS (Cybulska, 2004a, s. 8-9; Roguska, 2009b, s. 8).

nanych, że to politycy sami wybierają ze swego grona przedstawicieli do PE, 19\% - nie potrafiła udzielić jakiejkolwiek odpowiedzi). Warto dodać, iż w analizowanym okresie (kwiecień 2009 r.) zainteresowanie wyborami deklarowało jedynie 30\% ankietowanych, natomiast jako główną motywację do głosowania wskazywano obowiązek obywatelski - 41\% (ISP, 2009; Cybulska, 2009a, s. 1-2) ${ }^{9}$.

Badania pokazuja, że niewielkie znaczenie wyborów dla obywateli wcale nie oznacza, iż w społecznej ocenie to, kto reprezentuje Polskę w PE jest bez znaczenia. Zdaniem ankietowanych, wizerunek Polski na arenie międzynarodowej (78\%) oraz właściwa reprezentacja interesów polskich w UE (71\%) zależy właśnie od europosłów (Roguska, 2009b,

9 Kolejne argumenty to m.in.: chęć odsunięcia od władzy dotychczasowych rządzących czy brak sympatii dla określonych partii (głosowanie na ich niekorzyść). 
s. 4). Zatem, mimo iż w świadomości społecznej wybory do PE mają niewielkie znaczenie z punktu widzenia interesów poszczególnych jednostek, to jednak są relewantne dla państwa.

Wymienione powody absencji wyborczej wskazują zatem, że zaniechanie uczestnictwa w wyborach jest swego rodzaju protestem obywateli wobec działalności podmiotów politycznych czy aktualnej sytuacji politycznej, społecznej. Traktowanie wyborów jako drugorzędnych, niemających bezpośredniego wpływu na codzienne funkcjonowanie jednostek wydaje się sprzyjać takiej decyzji obywateli.

\section{Upolitycznienie kampanii profrekwencyjnych}

Wyrosłe z kampanii społecznych kampanie profrekwencyjne moga być, podobnie jak one ${ }^{10}$, posądzane o sprzyjanie poszczególnym podmiotom (konkretnym ugrupowaniom politycznym). Przykładem może być zainicjonowana przez Jarosława Kaczyńskiego (PiS) dyskusja nad treścią i znaczeniem hasła promującego kampanię profrekwencyjną realizowaną przed wyborami parlamentarnymi w 2007 roku (Kampania, 2007) ${ }^{11}$. Lider ubiegającej się wówczas o reelekcję partii przyczyn porażki swego ugrupowania doszukiwał się m.in. w rozpowszechnianiu (również w okresie ciszy wyborczej pod „pozorem” kampanii profrekwencyjnej) hasła „Zmień kraj. Idź na wybory”12 - jak dowodził Jarosław Kaczyński: „Gdyby to było: Idź na wybory, to OK., ale zmień Polskę to jednak była sugestia zmień rzqd. Przegraliśmy przez wielką kampanię zorganizowaną przeciwko nam" (Zmień kraj, 2008).

W 2009 roku autorzy raportu dotyczącego monitoringu kampanii wyborczych (Fundacja im. Stefana Batorego, 2009) zwrócili uwagę na kwestię wykorzystywania przez komitety wyborcze działań profrekwencyjnych w celu promowania określonych kandydatów. Przypadkiem opisanym w dokumencie były działania podejmowane przez prezydenta Bydgoszczy - Konstantego Dombrowicza, który swoim wizerunkiem

10 W przypadku stricte kampanii społecznych może pojawić się zarzut o wspieranie konkretnych przedsiębiorców, firm czy koncernów.

11 Kampanię prowadziło ponad 150 organizacji tworzących koalicję 21pazdziernika.pl.

${ }^{12}$ W kampanii promowano również hasła: „Parlament - zrób to sam” oraz „Nie pękaj. Dokonaj wyboru”. 
i nazwiskiem zachęcał na plakatach i billboardach mieszkańców miasta do udziału w eurowyborach. Sytuacja nie budziłaby wątpliwości gdyby nie fakt, iż jednym z kandydatów z ramienia PO był syn Dombrowicza o identycznym imieniu i nazwisku. Dodatkowo adres dotychczasowej prywatnej strony internetowej prezydenta (www.dombrowicz.pl) automatycznie przekierowywał internautę na stronę syna-kandydata (Fundacja im. Stefana Batorego, 2009, s. 9; Wom, 2009).

\section{Kampania profrekwencyjna 2004}

Po udanej kampanii referendalnej w 2003 roku w sprawie przystapienia Polski do Unii Europejskiej, podczas której zauważalny był wzrost liczby akcji profrekwencyjnych, co mogło być skorelowane z wiążącym charakterem referendum (Konstytucja, 1997) ${ }^{13}$, zarówno ze strony ośrodków rządowych ${ }^{14}$, jak również organizacji pozarządowych (podejmujących pierwsze próby stworzenia szerokiej koalicji na rzecz uświadamiania społeczeństwu istoty wyborów ${ }^{15}$ ), w 2004 roku trudno mówić o zaplanowanej na szeroką skalę kampanii profrekwencyjnej. Skromna kampania informacyjna w okresie kampanii wyborczej pozostała niezauważona, nie spełniła swej roli informacyjno-edukacyjnej, ani nie zmobilizowała do udziału w wyborach - Polacy byli niepoinformowani co do samych wyborów do PE, jak również roli PE w UE, zabrakło ,prawdziwej kampanii informacyjnej” (Czaplicki, 2004, s. 3). Media podkreślały znikomą wiedzę Polaków i zainteresowanie pierwszymi eurowyborami. Głośnym przykładem były rezultaty ankiety przeprowadzonej na dwa tygodnie przed wyborami przez jeden z regionalnych dzienników („Słowo Ludu”) wśród mieszkańców Radomia - żaden respondent nie był w stanie wskazać choćby jednego nazwiska kandydata do PE z regionu (Czaplicki, 2004, s. 2).

13 Art. 125, ust. 3 Konstytucji RP z 1997 r. brzmi: „Jeżeli w referendum ogólnokrajowym wzięło udział więcej niż połowa uprawnionych do głosowania, wynik referendum jest wiążący".

14 Np. działania podejmowane przez PKW czy w 2003 r. Biuro ds. Referendum Europejskiego kierowane przez Lecha Nikowskiego (SLD).

${ }^{15}$ W 2003 roku powstała koalicja złożona z różnych organizacji trzeciego sektora Inicjatywa Obywatelska „TAK w referendum”, część spośród tych organizacji współtworzyło także późniejsze koalicje w ramach kampanii profrekwencyjnych. 
Uboga pod względem budżetowym kampania wyborcza poszczególnych podmiotów politycznych (Czaplicki, 2004, s. 2) również cechowała się wysokim stopniem ogólności. Podejmowana przez komitety wyborcze problematyka de facto niewiele różniła się od tej akcentowanej w kampanii parlamentarnej, co dodatkowo mogło przyczynić się do zatarcia różnic i braku próby zrozumienia przez obywateli różnic między polskim a europejskim parlamentem. Podmioty polityczne podkreślały m.in. kwestie bezrobocia, korupcji, podatków czy w przypadku ugrupowań proeuropejskich - rozwoju gospodarczego.

Istotnym tematem podejmowanym przez polityków w kampanii zarówno w 2004, jak i w 2009 roku była kwestia dopłat dla rolników i funduszy strukturalnych. Podmioty polityczne, zwłaszcza w 2004 roku, mocno akcentowały wagę patriotyzmu, jednak wyłaniający się z większości przekazów komitetów wyborczych obraz polskości skonstatował Michał Czaplicki [Instytut Spraw Publicznych - przyp. M. A.-Sz.] słowami: ,,można dojść do wniosku, iż jest to kampania propagująca pobór do polskiej armii mającej walczyć o Polskę przeciwko siłom zła czyhającym w Unii Europejskiej” (Czaplicki, 2004, s. 7), spostrzeżenie to potwierdzała uwaga poczyniona przez polityka LPR Bogdana Pęka: „główny front walki o Polskę przenosi się do Parlamentu Europejskiego" (Czaplicki, 2004, s. 7). Wybory do PE w 2004 roku bez watpienia potraktowane zostały zatem przez ugrupowania polityczne jako preludium do przypadającej na 2005 rok kampanii prezydenckiej i parlamentarnej.

Jakościową zmianą w sposobie realizacji wyróżniała się kampania profrekwencyjna do PE w 2009 roku. Nowatorskie działania coraz śmielej podejmowane zwłaszcza przez organizacje pozarządowe w tym zakresie widoczne sąjuż we wcześniejszej kampanii poprzedzającej wybory parlamentarne w 2007 roku.

\section{Kampania profrekwencyjna 2009}

W 2009 roku widoczny jest profesjonalizm w tworzeniu kampanii profrekwencyjnych (współpraca z wyspecjalizowanymi agencjami) uwzględniający zasięg i heterogeniczność działalności podejmowanej w tym zakresie przez zróżnicowane podmioty. Poza lokalnymi i regionalnymi (najczęściej związanymi z organami jednostek samorządu terytorialnego) inicjatorami akcji zachęcających do głosowania, a także ogólnopolskimi (jak Centrum Edukacji Obywatelskiej czy koalicje tworzone przez organi- 
zacje pozarządowe, np. Koalicja 7 czerwca) w profrekwencyjne kampanie krajowe państw członkowskich włączyły się międzynarodowe podmioty (Parlament Europejski, MTV Networks International).

Aspektem wyróżniającym kampanie profrekwencyjne na tle kampanii społecznych jest dominacja pozytywnych emocji. Reklamy społeczne mają na celu nagłośnienie problemów społecznych, a także uświadomienie ich rangi i konsekwencji w przypadku podjęcia określonej decyzji, często oddziałując na odbiorców szokiem. Warto zwrócić uwagę, iż w zamyśle reklamy profrekwencyjnej prym zazwyczaj wiedzie pozytywna argumentacja, bazująca coraz częściej na humorze, który w konsekwencji ma zachęcić jednostki (zwłaszcza młode pokolenie) do aktywności wyborczej.

Analiza poczynań w ramach kampanii profrekwencyjnej w 2009 roku pozwala wnioskować, że jej wiodącą grupą docelową były właśnie osoby młode, internauci. Wspomniany target group był adresatem działań prowadzonych przez Koalicję 7 czerwca, w jej skład wchodziły różne organizacje społeczne, w tym Centrum Edukacji Obywatelskiej (Koalicja na rzecz gromadnego udziału w eurowyborach, 2009) ${ }^{16}$ w ramach kampanii zatytułowanej „Pępek Europy”. Oryginalne rozwiązanie zastosowane w przytoczonej kampanii polegało na akcentowaniu przede wszystkim aspektu rywalizacji (w tym przypadku gmin o miano miejscowości z najwyższą frekwencją wyborcza), tym samym niejako odstapiono od utartego już nieco schematu prostego przekazu informującego o dacie wyborów i sposobie głosowania (prawidłowego pod względem formalnym wypełnienia karty do głosowania). Motywem przewodnim kampanii była zamieszczona na witrynie internetowej Koalicji 7 czerwca (www.7czerwca.org.pl) interaktywna gra „Pępek Europy”, w której tytułowy pępek każdy internauta mógł przesunąć w stronę swojej miejscowości deklarując (poprzez kliknięcie) uczestnictwo w wyborach ${ }^{17}$. Na stronie internetowej koalicji zamieszczono również aplikację „Kalkulator frekwencyjny” - symulujący ostateczną liczbę reprezentantów regionu uzależnioną od wiel-

16 Koalicję tworzyły m.in.: Fundacja im. Stefana Batorego, Polska Konfederacja Pracodawców Prywatnych Lewiatan, Forum Obywatelskiego Rozwoju, Stowarzyszenie Komunikacji Marketingowej, Instytut Spraw Publicznych, Związek Firm Public Relations, Stowarzyszenie Szkoła Liderów, Fundacja Projekt: Polska, agencja reklamowa Saatchi \& Saatchi, Polska Fundacja im. Roberta Schumana, Centrum Edukacji Obywatelskiej, agencja reklamowa PZL, Mediacom. Warto dodać, iż część wspomnianych organizacji wchodziło w skład Koalicji 21 października prowadzącej kampanię profrekwencyjną przed wyborami parlamentarnymi w 2007 r.

17 Ostatecznie w rywalizacji wygrały gminy Podkowa Leśna i Czarna Woda. 
kości frekwencji wyborczej oraz link do witryny „Latarnik wyborczy” oferującej możliwość zweryfikowania zgodności preferencji potencjalnych wyborców z poglądami pretendentów do PE w 2009 roku (ilustracja 1).

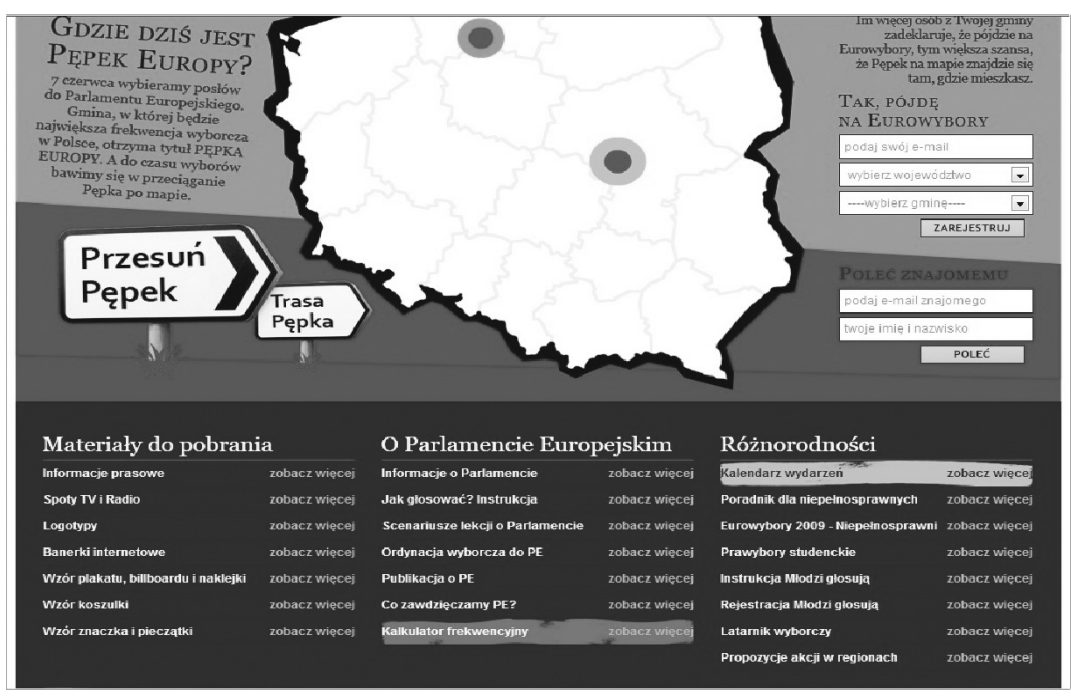

Ilustracja 1. Witryna internetowa Koalicji 7 czerwca

Źródlo: Koalicja na rzecz gromadnego udziału w eurowyborach, 2009.

Na skonstruowanym przez Centrum Edukacji Obywatelskiej wortalu www.latarnikwyborczy.pl, internauta odpowiadając na kolejne pytania mógł sprawdzić, który kandydat jest najbliższy jego przekonaniom. Warto wspomnieć, iż podobną funkcję pełniła witryna www.kandydaci2009.pl, założona przez organizację pozarządową Stowarzyszenie 61, na której wyborca mógł się zapoznać z wypełnionymi przez kandydatów ankietami zawierającymi pytania m.in. na temat doświadczenia zawodowego, poglądów czy celu kandydowania (Rzeplińska, 2009). W ramach kampanii „Pępek Europy” na uczelniach organizowano debaty z kandydatami, wśród uczniów zainteresowaniem cieszyły się happeningi „Pępkowe wróżby".

W kampanii 2009 wykorzystano (podobnie jak w 2007 r.) różnorodne formy promocji: spoty audiowizualne (rozpowszechniane w telewizji ogólnopolskiej i regionalnej, a także w Internecie), reklamy audytywne i wizualne (radio, Internet, prasa, billboardy i plakaty), a także gadżety (m.in. koszulki, naklejki, znaczki, pieczątki). 
Animowane spoty ${ }^{18}$ Koalicji 7 czerwca zobrazowane ludową symboliką opatrzono, jeden - słowami lektorki: „W Pupkach, w Cycowie, w Szczebrzeszynie, albo może w twojej gminie? Gdzie będzie pępek Europy? 7 czerwca.org.pl", drugi - dynamiczną piosenką ludową zespołu „Żywiołak”19. W kolejnych odsłonach reklam, ukazując z jednej strony zakrzątanych, z drugiej znużonych, zaspanych ludzi, Koalicja przypominała: „Nie przegap! Wybory do Parlamentu Europejskiego. Niedziela 7 czerwca 2009".

Wzorem Koalicji 7 czerwca pomysł rywalizacji między miastami podjęła i zrealizowała Fundacja Kopernikańska z Torunia. W ramach podjętej akcji próbowano zmobilizować prezydentów sasiednich miast Torunia i Bydgoszczy do zwiększenia aktywności w promowaniu wśród mieszkańców potrzeby podwyższenia frekwencji w wyborach, przekonując obu do złożenia deklaracji, że przegrany (a więc reprezentant miasta z niższą frekwencją) nie tylko złoży gratulacje rywalowi, ale również przez tydzień będzie nosić wpięty w marynarkę znaczek z napisem „Szacunek dla... - nazwa zwycięskiej miejscowości” (Mko, 2009). Kontynuacją owych działań był happening w centrum Torunia, którego uczestnicy, nawołując mieszkańców do aktywnego udziału w wyborach, zaprezentowali plakat z wizerunkiem Mikołaja Kopernika opatrzony hasłem: „Kto nie głosuje ten z Bydgoszczy!” (ilustracja 2).

Wśród licznych działań profrekwencyjnych podejmowanych w 2009 roku na uwagę zasługuje również akcja promocyjna witryny Glosuje.com.pl (Centrum Europejskie UW, 2013) ${ }^{20}$ - spoty audiowizualne rozpowszechniane $\mathrm{w}$ telewizji i $\mathrm{w}$ Internecie nawoływały do aktywnego udziału w wyborach oraz zapoznania się z zawartością wortalu, na którym można było $\mathrm{m}$. in. wypełnić test wykazujący stopień zbieżności poglądów internautów z ofertą wyborczą poszczególnych kandydatów. Bohaterami wspomnianych spotów utrzymanych w konwencji satyry byli aktorzy

18 Emisję reklam w telewizji poprzedził nadawany przed rozpoczęciem kampanii mający wzbudzić zainteresowanie widzów zwiastun (teaser).

19 Tekst piosenki brzmiał następująco: „Wyleciał Maćko z obory, pędzi chłopak na wybory, za nim młodzi, baby, chłopy, bliżej to do Europy. Poszły wójty i plebany i walili w barabany. Oj ta Europa cała będzie o Polsce słyszała. Zobaczą, że w naszej wsi Polacy, a nie gęsi. Mamy język i piętę, łeb na karku i piętę".

20 Twórcami inicjatywy oraz akcji promocyjnej reklam były: Centrum Europejskie UW, Instytut Nauk Ekonomicznych PAN, Uniwersytet Wileński, Fundacja im. K. Pułaskiego oraz Studio Agart. 


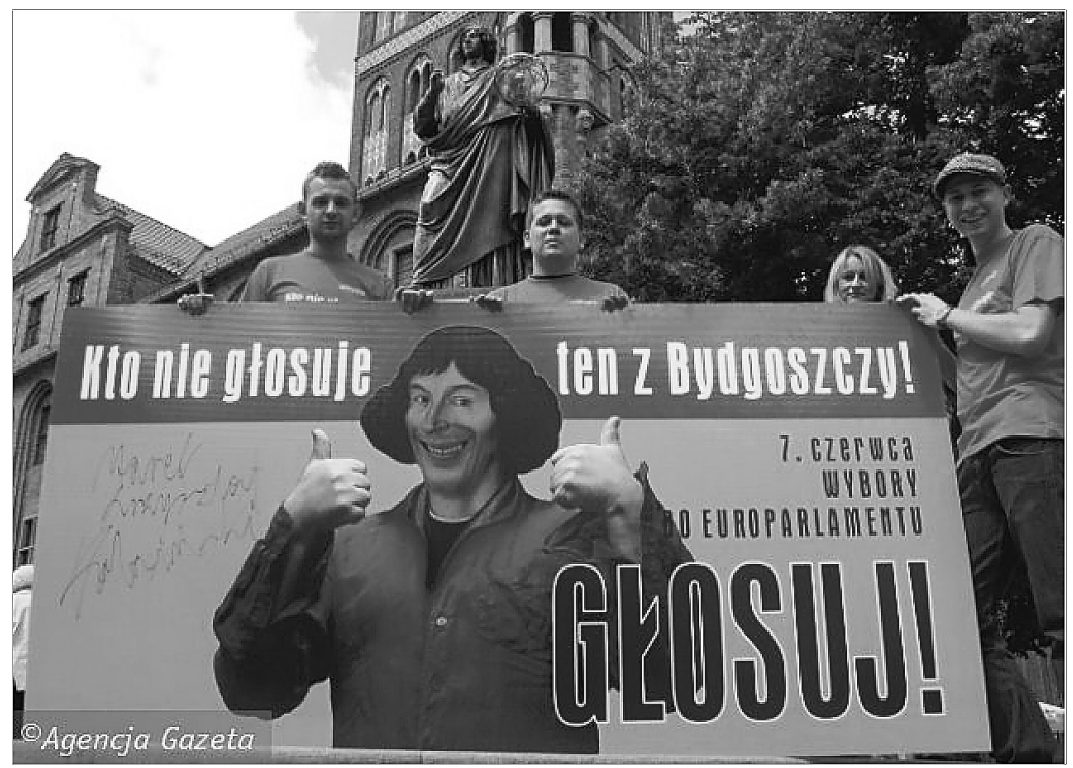

Ilustracja 2. Plakat Fundacji Kopernikańskiej z Torunia - kampania profrekwencyjna 2009

Źródło: Ber, 2009.

ucharakteryzowani na: Edwarda Gierka, Leonida Breżniewa i Chucka Norrisa.

Poza budową okolicznościowych witryn internetowych, podmioty promowały swe kampanie profrekwencyjne na portalach społecznościowych, tworzyły konta w serwisie YouToube, na którym dostępne były materiały audiowizualne, w tym wszystkie spoty.

W 2009 roku mobilizacji społeczeństwa do udziału w wyborach do Parlamentu Europejskiego miała służyć także kampania zorganizowana przez Urząd Komitetu Integracji Europejskiej wspólnie z Komisją Europejską Przedstawicielstwem w Polsce. Rozpowszechniania w ramach kampanii reklama audiowizualna skoncentrowana była na „wyliczeniu” konkretnych spraw, jakimi powinien zająć się wybrany przez społeczeństwo europoseł. Symbolami owych spraw były przedmioty ukradkiem wrzucane do walizki z garderobą potencjalnego kandydata przez: policjanta (lizak - „bezpieczeństwo”), miłośnika przyrody (kwiatek w doniczce - „ochrona środowiska”), młodą kobietę (biustonosz - „równouprawnienie kobiet") oraz rolnika (bochenek chleba zawinięty w serwetę - ,pomoc dla 
wsi”). W puencie przekazu lektor podkreślał, iż o tym kto zostanie europosłem, a zatem na jakie zagadnienia zwróci uwagę w trakcie swej kadencji zadecyduje wyborca: „Ty wybierzesz! Ty zdecydujesz! Nie zmarnuj swojej szansy! 7 czerwca zagłosuj w wyborach do Parlamentu Europejskiego".

Nowatorskim pomysłem Parlamentu Europejskiego realizowanym również ramach kampanii 2009 „Ty decydujesz” były kabiny multimedialne docierające w różne zakątki miast europejskich (w Polsce były w Warszawie, Krakowie i Łodzi), w których każdy obywatel miał możliwość nagrania swej wypowiedzi na temat UE adresowanej i finalnie przesłanej eurodeputowanym. Nietypową propozycją promowania wyborów była akcja „tajnych żółto-niebieskich agentów”, powołanych celem dotarcia do znanej osobistości w każdym z 27 krajów UE z maskotką, która przekazywana była (w analogii do sztafety) z rąk do rąk, by w końcu trafić do danej gwiazdy (Man, 2009) ${ }^{21}$.

Podkreślenia wymaga także inicjatywa profrekwencyjna Komisji Europejskiej zrealizowana we współpracy z MTV Networks International opatrzona pod hasłem: „Halo Europo, słyszysz mnie?” (MTV, 2009). Poza rozpowszechnianiem spotów audiowizualnych adresowanych do młodzieży (bohatera reklam prezentowanego z megafonami na ulicach Londynu, Rzymu, Paryża), skonstruowano zachęcającą internautów do aktywności witrynę internetową www.canyouhearme.eu - tworzącą forum wymiany poglądów młodych ludzi na temat UE oraz dającej możliwość zaprezentowania swoich oczekiwań, propozycji działań względem Parlamentu Europejskiego. Internauci nie mogący uczestniczyć w zorganizowanej 30 kwietnia 2009 roku w Berlinie, Mediolanie i Pradze tematycznej akcji, podczas której zgromadzeni ludzie (symbolicznie prezentujący głos młodego pokolenia Europejczyków) wspólnie wykrzyczeli hasło kampanii „Can you hear me Europo”, mogli dołączyć publikując nagrania swojego okrzyku na wspomnianej stronie - autor najpopularniejszego w sieci okrzyku został nagrodzony biletami na jeden z największych festiwali muzycznych MTV w Europie (MTV, 2009).

Oryginalnym był zrealizowany w 2009 roku wspólny projekt Parlamentu Europejskiego, Europejskiej Agencji Kosmicznej i belgijskiego astronauty Franka de Winne (Parlament Europejski, 2009). Pierwszy w historii przesłany z kosmosu apel internauty o udział w głosowaniu został

21 W Polsce maskotka trafiła do aktora Marcina Dobrocińskiego. 
zwizualizowany i zamieszczony w Internecie (ilustracja 3). W krótkiej odezwie internauta przekonywał dlaczego warto wziąc udział w wyborach i jak wiele Europejczycy mogą osiagnąć współpracując.
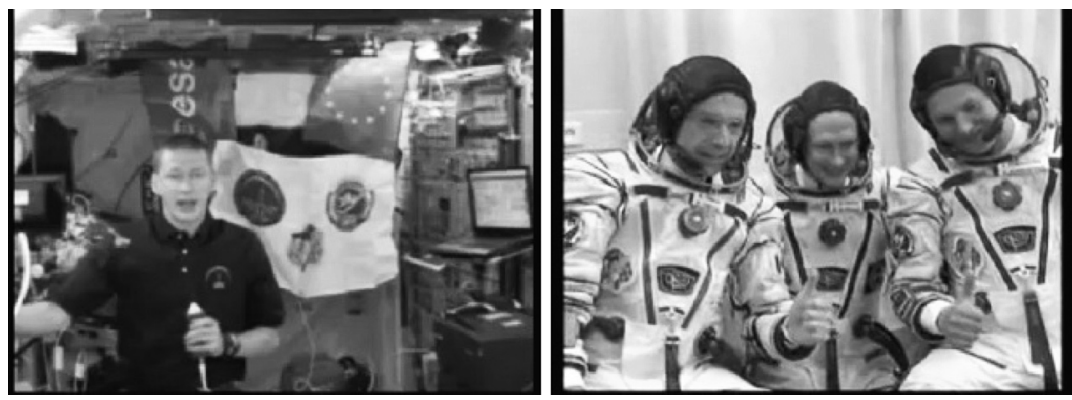

Ilustracja 3. Kadry ze spotu z udziałem astronauty Franka de Winne z 2009 roku Źródło: Parlament Europejski, 2009.

Kampania do PE w 2009 roku była pierwszą kampanią, w której podmioty (zarówno polityczne, jak i społeczne) prowadziły tak intensywne działania promocyjne w Internecie. Wspomniane już działania Parlamentu Europejskiego dopełniała strona internetowa (www.wybory2009.eu), na której można było znaleźć m.in. omówienie podstawowych zapisów ordynacji wyborczej, informacje na temat przygotowań do wyborów w państwach członkowskich, komentarze Europejczyków o UE i PE czy zakładkę „10 powodów, dla których warto zagłosować”.

Analizowaną kampanię skierowano głównie do młodych wyborców, stanowiących współcześnie grupę cechującą się najwyższym wskaźnikiem absencji wyborczej spośród wszystkich grup wiekowych (Cybulska, 2004a, s. 1; Roguska, 2009b, s. 5) ${ }^{22}$. Z badań wynika, że wiedza młodego pokolenia na temat wyborów (procedury głosowania, sposobu wyboru deputowanych do PE, a nawet orientacji odnośnie organów wybieranych w wyborach samorządowych) jest niewielka. Rodzi się zatem pytanie: na ile system edukacji szkolnej przybliża uczniom wiedzę na temat funkcjonowania państwa demokratycznego? W tej sytuacji nie dziwi również

22 Tendencja taka zauważalna jest w różnych badaniach, np. z przywoływanych już powyborczych badań CBOS z lipca w 2004 i w 2009 r. wynika, że w grupie wiekowej 18-34 lata z prawa wyborczego skorzystało w 2004 r. tylko 18\%, natomiast w 2009 r. - 23\% ankietowanych. 
fakt, iż młodzi ludzie coraz rzadziej postrzegają udział w wyborach w kategorii obywatelskiego obowiązku (Wyborca 2.0, 2012, s. 73). Skoncentrowanie działań kampanijnych głównie na możliwościach oferowanych przez Internet wydaje się być szansą na dotarcie do „pokolenia 2.0”, tym bardziej, że korzystanie z tego medium jest jednym z wymiarów najmocniej różnicujących młodszą i starszą generację (Wyborca 2.0, 2012, s. 73-74) ${ }^{23}$, a młodzież wskazuje Internet jako podstawowe i często jedyne źródło informacji o polityce i sprawach publicznych. W tym kontekście zasadnicze wydaje się rozważenie realnej możliwości głosowania przez Internet, zwłaszcza, że takiemu rozwiązaniu młodzi wyborcy są bardzo przychylni, co wynika „nie tyle z konieczności i chęci przezwyciężenia barier w uczestnictwie w wyborach, co raczej z oczekiwania dostosowania procedur demokratycznych do swojego stylu życia" (Wyborca 2.0, 2012, s. 75). Możliwości integracji internautów dzięki oddolnej organizacji działań ukazał protest przeciwko ACTA zorganizowany na początku 2012 roku (Wit, KK, 2012) ${ }^{24}$.

\section{Wnioski}

Zaangażowana oraz merytoryczna kampania wyborcza podmiotów politycznych posiłkowana zarówno rządową i pozarządową kampanią informacyjną z pewnością byłaby krokiem ku zwiększeniu wiedzy, a w konsekwencji również świadomości polskich obywateli co do roli i funkcjonowania PE, w rezultacie doprowadzając do zwiększenia frekwencji wyborczej.

Kolejne kampanie pokazują, że to głównie media przyczyniają się do informowania społeczeństwa co do przebiegu kampanii, znaczenia wyborów, prezentacji kandydatów. Zgodnie z modelem racjonalnego wyborcy „obywatel lepiej poinformowany będzie bardziej skłonny uczestniczyć w życiu politycznym, choćby dzięki temu, że odpowiedni zasób informacji ułatwia podjęcie podstawowych decyzji związanych z uczestnictwem społecznym w sferze polityki: np. czy i na kogo głosować” (Kolczyński,

23 Z badań wynika, że z Internetu korzysta 93\% osób w wieku 16-24 lata, niemal $86 \%$ internautów to osoby w wieku 25-34 lata, najniższy wskaźnik notowany jest w najstarszej grupie wiekowej (50+) - niespełna 30\% użytkowników.

24 Szczegółową relację przebiegu protestu w Polsce opisywało m.in. Polskie Radio. 
2007, s. 165). Jeśli w mediach temat kampanii do PE zostaje ukazany jako drugorzędny istnieje duże prawdopodobieństwo, że w identyczny sposób będzie postrzegany również przez obywateli (Dobek-Ostrowska, 2011, s. 191-210; Piontek, Hordecki, 2011, s. 211-223; Łódzki, 2011, s. $225-242)^{25}$.

Biorąc pod uwagę skuteczność oddziaływania na odbiorców w marketingu komercyjnym reklamy świadectwa w różnej formie - autorytetów, osób znanych i cieszących się szacunkiem czy tzw. „zwykłych ludzi” (Cialdini, 2002, s. 187-191) ${ }^{26}$ trafionym pomysłem wydaje się zastosowanie jej także w kampaniach profrekwencyjnych poprzedzających eurowybory. Technika ta od kilku lat odnosi pozytywne rezultaty w USA, w Polsce stosowana jest głównie w marketingu komercyjnym i politycznym, szerzej wykorzystana została w ostatnich parlamentarnych kampaniach profrekwencyjnych w 2007 i 2011 roku oraz w kampanii prezydenckiej w 2010 roku. Najwięcej spotów tego rodzaju skierowanych było do najmłodszych wyborców, którzy wychowani w otoczeniu mediów masowych chętniej naśladują celebrytów niejednokrotnie wyznaczających standardy postępowania (Szpunar, 2010, s. 111), równie skuteczną formą ,świadectwa” jest rekomendacja rówieśnika (marketing wirusowy).

Zdecydowana większość dotychczasowych działań profrekwencyjnych w Polsce (wyjątkiem może być w kontekście artykułu jedynie kampania w 2009 r.) charakteryzowała się okazjonalnością, krótkoterminowością, koncentrując się przy tym przede wszystkim na „technicznej” stronie aktu głosowania. Taktyka taka może być skuteczną co najwyżej w odniesieniu do grup docelowych wyrażających gotowość lub rozważających aktywne uczestnictwo w wyborach. Wydaje się, że priorytetowym celem kampanii profrekwencyjnych (czego oznaki pojawiły się w ostatnich krajowych kampaniach parlamentarnych, w tym w kampanii do PE w 2009 r.) powinna być koncentracja działań na próbie uświadomienia obywatelom znaczenia aktu głosowania, zwłaszcza w odniesieniu do późniejszego kształtu codziennego funkcjonowania i jakości życia pojedynczych jednostek czy grup społecznych.

25 Badania prowadzone w odniesieniu do eurowyborów w 2009 r. wskazują, że media (inaczej niż w przypadku elekcji do instytucji krajowych) nie były zainteresowane ekspozycją tego tematu w swojej agendzie.

26 Robert Cialdini podkreśla, że ludzie mają skłonność do bezwarunkowego ulegania autorytetom, co jest następstwem zasad wpajanych w dzieciństwie i w procesach socjalizacji wtórnej. 
Permanentne działania profrekwencyjne czerpiące z dorobku marketingu komercyjnego i politycznego (wspomagane lub realizowane przez profesjonalne agencje reklamowe $\mathrm{e}^{27}$ ), prowadzone za pomocą różnorodnych kanałów komunikacji przez rozmaite podmioty (na poziomie lokalnym, regionalnym, ogólnopolskim czy w końcu międzynarodowym), zachęcające obywateli do oddolnego angażowania się, wzmocnione spójną kampanią w okresie przedwyborczym mogą stać się elementem przyczyniającym się do poprawy frekwencji wyborczej.

Wydaje się, iż realizowana na szeroką skalę edukacja obywatelska w tym zakresie powinna kłaść nacisk nie tylko na aspekty teoretyczne, ale przede wszystkim praktyczne, obrazujące i uświadamiające obywatelom wagę i znaczenie wpływu ich głosu na kształt polityki, a w konsekwencji na jakość ich życia.

\section{Bibliografia}

Adamik-Szysiak M. (2012), Telewizyjna reklama polityczna $w$ Polsce $w$ latach 2005-2010, Wydawnictwo Uniwersytetu Marii Curie-Skłodowskiej, Lublin.

Bartosik Ł. (2010), Kampanie profrekwencyjne przed wyborami do Parlamentu Europejskiego 2009 roku jako rodzaj marketingu spolecznego, w: Wybory do Parlamentu Europejskiego. Media i marketing polityczny, red. M. Jeziński, W. Peszyński, A. Seklecka, TNOiK Dom Organizatora, Toruń.

Ber (2009), Kto nie glosuje ten z Bydgoszczy!, http://www.wiadomosci.gazeta.pl/ wiadomosci/1,114873,6645541,Kto_nie_glosuje_ten_z_Bydgoszczy_html, 20.01.2013.

Centrum Europejskie UW (2013), Glosuje.com.pl-na YouTube, http://www.ce.uw.edu.pl/ mobile/aktualnosci-z-ce/pokaz-komunikat,glosuje.com.pl-na-you-tube, 20.01.2013.

Cialdini R. (2002), Wywieranie wplywu na ludzi, Gdańskie Wydawnictwo Psychologiczne, Gdańsk.

Cybulska A. (2004a), Głosujacy i nie głosujacy o swych decyzjach w wyborach do Parlamentu Europejskiego - analiza powyborcza, lipiec, BS/114/2004, CBOS, Warszawa.

27 W kampanii 2009 działania podejmowane w ramach kampanii „Pępek Europy” czy „Glosuje.com.pl” realizowane były przez profesjonalne agencje przyłączające się do organizacji tworzonej na rzecz kampanii profrekwencyjnej, były to odpowiednio: Saatchi \& Saatchi i PZL oraz Studio Agart. 
Cybulska A. (2004b), Wybory do Parlamentu Europejskiego, czerwiec, BS/95/2004, CBOS, Warszawa.

Cybulska A. (2009a), Wybory do Parlamentu Europejskiego, kwiecień, BS/63/2009, CBOS, Warszawa.

Cybulska A. (2009b), Wybory do Parlamentu Europejskiego, maj, BS/82/2009, CBOS, Warszawa.

Czaplicki M. (2004), Pierwsze wybory europejskie w Polsce, ISP, „Analizy i Opinie” 2004, nr 25, http://www.isp.org.pl/files/5594235580912379001159432905.pdf, 20.01.2013.

Dobek-Ostrowska B. (2004), Media masowe i aktorzy polityczni w świetle studiów nad komunikowaniem politycznym, Wydawnictwo Uniwersytetu Wrocławskiego, Wrocław.

Dobek-Ostrowska B. (2011), Nagtośnienie kampanii do Parlamentu Europejskiego w 2009 r. przez dzienniki opiniotwórcze ,, Gazeta Wyborcza” $i$, Rzeczpospolita", w: Studia empiryczne nad komunikowaniem politycznym w Polsce, red. B. Dobek-Ostrowska, K. Majdecka, Wydawnictwo Uniwersytetu Wrocławskiego, Wrocław.

Entman R. M. (1993), Framing : Towards Clarification of a Fractured Paradigm, „Journal of Communication" vol. 43, $\mathrm{nr} 4$.

Fundacja im. Stefana Batorego (2009), Finansowanie kampanii wyborczej do Parlamentu Europejskiego 2009 r. Raport Wstęny, http://www.batory.org.pl/doc/ raport_monit_kamp_PE_10062009.pdf, 20.01.2013.

Instytut Spraw Publicznych (2009), Uczestnictwo Polaków w wyborach - postawy wobec nadchodzacych wyborów do Parlamentu Europejskiego, kwiecień, http://www.isp.org.pl/uploads/filemanager/Program\%20Prawa\%20i\%20Instytucji\%20Demokratycznych/UczestnictwoPolakwwobec-PolacywobecnadchodzcychwyborwdoParlamentuEuropejskiego.pdf, 20.01.2013.

Kampania spoleczna Zmień kraj. Idź na wybory. Raport o przebiegu kampanii i rekomendacje na przyszłość (2007), red. J. Bełdowski, P. Chylińska, http://www.for.org.pl/ upload/File/raporty/Raport_o_Kampanii_Zmien_kraj._Idz_na_wybory_FINAL.pdf, 20.01.2013.

Koalicja na rzecz gromadnego udziału w eurowyborach (2009), www.7czerwca.org.pl, 20.12.2012.

Kolczyński M. (2007), Strategie komunikowania politycznego, Wydawnictwo Uniwersytetu Śląskiego, Katowice.

Konstytucja Rzeczypospolitej Polskiej z dnia 2 kwietnia 1997 r., Dz. U. 1997, Nr 78, poz. 483.

Łódzki B. (2011), Nagłośnienie kampanii do Parlamentu Europejskiego w 2009 r. Analiza zawartości telewizyjnych audycji informacyjnych TVP1, TVN i TV Polsat, w: Studia empiryczne nad komunikowaniem politycznym w Polsce, 
red. B. Dobek-Ostrowska, K. Majdecka, Wydawnictwo Uniwersytetu Wrocławskiego, Wrocław.

Man (2009), Facebook przyciagnie wyborców do urn?, 20.05.2009, http://www.rp.pl/ artykul/301883,308383.html, 20.01.2013.

McCombs M. (2008), Ustanawianie agendy. Media masowe i opinia publiczna, Wydawnictwo Uniwersytetu Jagiellońskiego, Kraków.

Mko (2009), Czy prezydent Zaleski będzie chwalit Bydgoszcz?, http://www.torun.gazeta.pl/torun/1,48723,6592201,Czy_prezydent_Zaleski_bedzie_chwalil_Bydgoszcz_html, 20.01.2013.

MTV (2009), Decydujaca faza kampanii frekwencyjnej »Halo Europo, styszysz mnie? «, http://www.mtv.pl/news/Decyduj-ca-faza-kampanii-frekwencyjnej-8222-Halo-Europo-s-yszysz-mnie-8221-2258959/, 20.01.2013.

Parlament Europejski (2009), Europejski astronauta zachęca do udziatu w wyborach do Parlamentu Europejskiego z orbity okołoziemskiej, 5.06.2009, http://www.europarl.europa.eu/sides/getDoc.do?type=IM-PRESS\&reference=20090603IPR 56585\&language $=\mathrm{PL}, 20.01 .2013$.

PKW (2004), Wybory do Parlamentu Europejskiego 2004, www.pe2004.pkw.gov.pl, 20.01.2013.

PKW (2009), Wybory do Parlamentu Europejskiego 2009, www.pe2009.pkw.gov.pl, 20.01.2013.

Piontek D., Hordecki B. (2011), Nagłośnienie kampanii do Parlamentu Europejskiego w 2009 r. przez dzienniki tabloidowe, w: Studia empiryczne nad komunikowaniem politycznym w Polsce, red. B. Dobek-Ostrowska, K. Majdecka, Wydawnictwo Uniwersytetu Wrocławskiego, Wrocław.

Raciborski J. (1997), Polskie wybory. Zachowania wyborcze społeczeństwa Polskiego w latach 1989-1995, Scholar, Warszawa.

Roguska B. (2009a), Postrzeganie instytucji unijnych, kwiecień, BS/54/2009, CBOS, Warszawa.

Roguska B. (2009b), Wybory do europarlamentu w powyborczych deklaracjach Polaków, lipiec, BS/110/2009, CBOS, Warszawa.

Rzeplińska R. (2009), www.kandydaci2009.pl-obywatelski monitoring kandydatów do parlamentu Europejskiego, 20.05.2009, http://www.wiadomosci.ngo.pl/ wiadomosci/456153.html, 20.01.2013.

Szpunar M. (2010), W stronę nowych mediów, Wydawnictwo A. Marszałek, Toruń.

Wom (2009), Wybory do PE: po łaczach do syna; strona Konstantego Dombrowicza przekierowuje na strone syna, 20.05.2009, http:/www.pomorska.pl/apps/pbcs.dll/ article?AID=/20090520/EUROPARLAMENT/112306088, 20.01.2013.

Wyborca 2.0 (2012), red. D. Batorski i in., ISP, Warszawa.

Wit K. K. (2012), ACTA. Protest internautów - w sieci $i w » r e a l u \lll, ~ 24.01 .2012$, http://www.polskieradio.pl/5/3/Artykul/522978,ACTA-Protest-internautow-w-sieci-i-w-realu, 20.01.2013. 
»Zmień kraj« zmienito kraj? (2008), http://www.kampaniespoleczne.pl/kampanie.php?kampania_id=67\&action=szczegoly\%3E, 20.01.2013.

\title{
Pro-attendance campaigns and the attitudes of Poles in the context of elections to the European Parliament
}

\begin{abstract}
Summary
The article is a part of the reflections on the meaning of pro-attendance campaigns in the context of the increasing election absence in Poland. The considerations concentrate on the causes of electoral passivity and the steps taken by various entities (on the local, regional, national and international level) to encourage citizens to take part in elections. The period of empirical research includes two previous Polish campaigns preceding the elections to the European Parliament in 2004 and 2009. The theoretical basis of the research is provided by the concept of framing and the theory of rational choice. Special attention is paid to the original elements of communication strategies in the campaigns run by non-governmental organizations, national and international institutions. Additionally, allegations against the politicization of pro-attendance campaigns are discussed.

In the light of the research results, the pro-attendance campaign in 2004 was primarily focused on informing potential voters about the voting procedure. Addressed mainly to the younger generation of voters, the campaign from 2009 revealed a qualitative change in the way of approaching and implementing the pro-attendance campaigns (use of the potential of the Internet, organization of actions integrating young voters, civic education combined with entertainment).
\end{abstract}

